\title{
Effect of Garcinia kola seeds supplemented diet on growth performance and gonadal development of Oreochromis niloticus juveniles breed in ponds
}

\author{
Paulin Nyadjeu ${ }^{1 *}$ (D), Jeannette Angoun ${ }^{1}$, Ngwasiri Pride Ndasi ${ }^{2}$ and Minette Eyango Tabi-Tomedi ${ }^{1}$
}

\begin{abstract}
Background: Despite the favorable geo-climatic potential of Cameroon, the national production of tilapia remains low due to poor tilapia growth reported by fish farmers. One of the underlying reasons is the early female maturation at a very small size and precocious breeding in earthen ponds, resulting in overpopulation which leads to stunted growth and therefore to the production of unmarketable fish size. Studies have shown that dietary supplementation of G. kola enhanced growth in young Clarias gariepinus and Oreochromis niloticus. It was also reported that G. kola inhibited spawning in Tilapia adult females. Therefore, this study sought to assess the effects of Garcinia kola as growth promoter and inhibitor of gonadal development in young Oreochromis niloticus.
\end{abstract}

Methods: A total of 108 juveniles weighing $13.32 \pm 0.62 \mathrm{~g}$ were randomly distributed in 9 hapas of 12 fishes each (9 females and 3 males) and fed for 70 days with three isonitrogenous diets, 40\% crude protein with increasing Garcinia kola supplementation levels of 0 (normal diet), $6 \%$ and $10 \%$ (experimental diets). Physico-chemical parameters of the water (temperature, dissolved oxygen, $\mathrm{pH}$, nitrate, nitrite, ammonia, and transparency) were measured twice a week. Every 14 days, fish were harvested, counted, and weighed. At the end of the experiment, three fish of each sex per replicate were sacrificed and their gonad and liver collected and weighed. Data were statistically analyzed using oneway analysis of variance repeated measure followed by Newman-Keuls multiple tests.

Results: The results showed that all physico-chemical parameters of the water were within the recommended values for Tilapia culture. Tilapia fed 6\% Garcinia kola supplemented diet displayed higher final body weight in males (38.60 \pm $3.50 \mathrm{~g})$ and females $(36.77 \pm 3.62 \mathrm{~g})$ compared to those receiving normal diet $(36.23 \pm 1.36 \mathrm{~g}$ and $25.87 \pm 3.32 \mathrm{~g}$; respectively to the final body weight in males and females). The gonadosomatic index and hepatosomatic index indicated no significant variation in males while in females, these were significantly low in the experimental fish compared to control fish.

Conclusion: The results of this study demonstrated that supplementation of $G$. kola seeds in diets of young Tilapia improved growth performance and impaired gonadal development in females.

Keywords: Oreochromis niloticus, Garcinia kola, Growth, Gonad development

\footnotetext{
* Correspondence: epauka@yahoo.fr

${ }^{1}$ The University of Douala, Institute of Fisheries and Aquatic Sciences of

Yabassi, P.O. Box: 7236, Douala, Cameroon

Full list of author information is available at the end of the article
}

(c) The Author(s). 2019 Open Access This article is distributed under the terms of the Creative Commons Attribution 4.0 International License (http://creativecommons.org/licenses/by/4.0/), which permits unrestricted use, distribution, and

reproduction in any medium, provided you give appropriate credit to the original author(s) and the source, provide a link to the Creative Commons license, and indicate if changes were made. The Creative Commons Public Domain Dedication waiver (http://creativecommons.org/publicdomain/zero/1.0/) applies to the data made available in this article, unless otherwise stated. 


\section{Background}

In Africa, particularly in Cameroon, fish food represents the primary source of animal protein. It offers better types of essential minerals, amino acids and is low in undesirable saturated fats (Hussain, 1986). To cope up with nutritional requirements of increasing population, aquaculture is considered as the only possible solution to increase fish production. Tilapia being an important food fish worldwide, significant developments have been recorded during the last three decades in its farming. About 85 countries worldwide are involved in fish farming and about $98 \%$ of tilapia produced there are grown outside their original habitats (Shelton, 2002). It provides one of the most important sources of animal protein and income throughout the world (Sosa et al. 2005). In some African countries such as in Egypt, the culture of Nile tilapia (Oreochromis niloticus) has increased dramatically in the last few years; while in Cameroon the global production remains insignificant despite the natural potential of the country. One of the major drawbacks to tilapia culture is the early female maturation at very small size (15-30 g) (Mair and Little, 1991; Popma and Lovshin, 1995), and precocious breeding in earthen ponds resulting in overpopulation which often leads to stunted growth. Mair and Little (1991) enumerated various methods and techniques available for the control of prolific breeding in tilapia. However, each technique or method has its own limitations. Monosex culture of all-male populations, which exhibits faster growth rates and which is usually produced through androgenous hormone sex reversal, is the preferred option, and is used extensively in the countries that produce large numbers of tilapia like China (Phelps, 2006). Considering the problem associated with the use of androgenous hormonal treatment, such as environmental and public health concerns and the limitations of existing methods and techniques documented by Mair and Little (1991), there is a need to explore other technologies to control undesirable tilapia recruitment in ponds using natural reproduction inhibitors found in plants to enhance better growth and improved flesh (Jegede, 2010). Garcinia kola commonly called Bitter kola belongs to the family Clusiaceae. It is a multipurpose tree indigenous to West and Central Africa (Manourová et al. 2019). The seed of G. kola is traditionally served to visitors for entertainment; it is also chewed by men as an aphrodisiac or used to prevent or relieve colic disorders or cure head or suppressed cough (Madubunyi, 2010). Previous studies on rats and poultry have shown that inclusion of G. kola seeds in powder and methanolic extracts form improved their growth performance (Oluyemi et al. 2007). Moreover, studies on Oreochromis niloticus have shown that dietary supplementation of G. kola seeds powder promotes the growth performance. It was also shown that dietary supplementation of G. kola seeds powder inhibits spawning in Oreochromis niloticus adult females; while in Tilapia fry, it was demonstrated that supplementation of $G$. kola can induce sex conversion (Sulem-Yong et al. 2018; Tigoli et al. 2018). To our knowledge, this study is the first on the effect of dietary inclusion of G. kola on gonadal development in nonpuber Oreochromis niloticus. Therefore, the present work was undertaken to evaluate the effect of dietary supplementation of Garcinia kola seed powder on growth performances and gonadal development of Oreochromis niloticus juveniles.

\section{Methods}

\section{Collection and acclimation of experimental fish}

The experiment was carried out in a small-scale private farm located at Bomabom (LN: $3^{\circ} 41^{\prime} 0^{\prime \prime}-{ }^{\circ} 46^{\prime} 30^{\prime \prime}$ and LE: $\left.1^{\circ} 7^{\prime} 30^{\prime \prime}-11^{\circ} 13^{\prime} 0^{\prime \prime}\right)$ in the central region of Cameroon. A total of 108 juveniles of Oreochromis niloticus were used; each weighing $13.32 \pm 0.62 \mathrm{~g}$ with an average length of $8.76 \pm 0.41 \mathrm{~cm}$. They were randomly distributed in triplicate into 9 hapas (made up of mosquito net cloth with size $\left.1^{\prime} \times 1^{\prime} \times 0.5^{\prime}\right)$ of 12 juveniles each (9 females and 3 males). The hapas suspended in an earthen pond $\left(800 \mathrm{~m}^{2}\right)$ with the help of four bamboo poles, one at each corner of the cage. The hapas were suspended in the pond such that three-quarters of each hapa was submerged in water whereas one-quarter remained outside. The roof of the hapas was covered with mesh to stop the experimental fish from jumping out and to prevent natural predators (snakes, kingfishers, frogs) from getting in. The fish were then allowed to acclimatize for 4 days prior to the experiment. During the acclimation, the fish were fed with normal diet.

\section{Experimental diet formulation and preparation}

A balanced dietary ration formula was prepared to meet the nutritional requirements of Nile tilapia according to NRC (2011) (Table 1). Three isonitrogenous diets were prepared: an unenriched control diet plus two test diets. The test diets were supplemented with 6\% and 10\% Garcinia kola at the expense of maize meal. In preparing experimental diets, the dried ingredients were ground into fine particles. After weighing and mixing manually for $10 \mathrm{~min}$, the preparations were moistened with warm water $\left(400 \mathrm{ml} \mathrm{kg}^{-1}\right)$ and mixed for another $20 \mathrm{~min}$. During the mixing, palm oil was added slowly along with warm water to achieve a proper consistency. The resulting mixture was then passed through a meat extruder to obtain a 2-mm pellet. The "spaghetti-like" strands were sun-dried and stored in airtight containers prior to use. The chemical composition of the test diets was analyzed by standard methods (AOAC, 1990). Moisture was analyzed by drying the sample in an air convection oven at $105^{\circ} \mathrm{C}$ overnight. Crude protein was analyzed by the Kjeldahl method after acid digestion $(\%$ crude protein $=$ 
Table 1 Formulations and proximate composition of experimental diets ( $\mathrm{g} / 100 \mathrm{~g}$ dry weight)

\begin{tabular}{llll}
\hline Ingredients & $\begin{array}{l}\text { Normal } \\
\text { diet }\end{array}$ & $\begin{array}{l}\text { Normal diets } \\
+ \text { G. kola }(6 \%)\end{array}$ & $\begin{array}{l}\text { Normal diets } \\
+ \text { G. kola 10\% }\end{array}$ \\
\hline Fish meal & 26 & 26 & 26 \\
Garcinia kola meal & $/ /$ & 6 & 10 \\
Soybean cake & 23 & 23 & 23 \\
Cottonseed cake & 22 & 22 & 22 \\
Maize meal & 10 & 4 & 0 \\
Wheat bran & 10 & 10 & 10 \\
Palm oil & 4 & 4 & 4 \\
Premix & 5 & 5 & 5 \\
Total & 100 & 100 & 100 \\
Proximate composition (\%) & & \\
Protein & 40.47 & 40.03 & 39.73 \\
Lipid & 13.23 & 13.14 & 13.12 \\
Ash & 12.75 & 12.71 & 12.68 \\
Moisture & 7.74 & 8.04 & 7.94 \\
Dry matter & 92.26 & 91.96 & 92.06 \\
Energy (kcal/100 g) & 420.63 & 418.17 & 417.20 \\
\hline
\end{tabular}

$\%$ nitrogen $\times 6.25$ ) while crude lipid was determined by extraction with petroleum ether using the Soxhlet method. The ash content in the diet was analyzed by combustion of samples in a muffle furnace at $550{ }^{\circ} \mathrm{C}$ for $12 \mathrm{~h}$ (Table 1).

\section{Experimental design}

Mixed-sex Nile tilapia $O$. niloticus were used in the feeding trial. At the initiation of the experiment, individual weight and length of all fishes per treatment were measured for determination of both initial weight and length. The acclimatized juveniles were randomly distributed in three replicates in 9 hapas each at a stocking density of 12 fish per hapas ( 9 females and three males). In the first triplicate, fish were fed with normal diet to serve as controls while in the second and third triplicates, they were fed with the Garcinia kola supplemented diet at rates of $6 \%$ and $10 \%$, respectively. Fish were hand-fed four times per day (08:00 a.m., 11:00 a.m., 14:00 p.m. and 17:00 p.m. respectively) at a rate of $5 \%$ of their body weight per day. Feeding rates were adjusted every 14 days for 70 days based on the weight gain of each group of fish per 14 days. Physico-chemical parameters of the water in each hapa such as temperature was measured using a maximumminimum thermometer; dissolved oxygen $\left(\mathrm{O}_{2}\right)$ was determined using JBL Test Kits, $\mathrm{pH}$, nitrate $\left(\mathrm{NO}_{3}{ }^{-}\right)$, nitrite $\left(\mathrm{NO}_{2}{ }^{-}\right)$, and ammonia $\left(\mathrm{NH}_{3}\right)$ were measured twice a week before feeding using test strips (JBL Easy Test 6in1) while transparency was monitored using a Secchi disk (Table 2).

\section{Data collection}

Growth performances, feed utilization, and somatic indices were assessed by determination of weight gain (WG), specific growth rate (SGR), feed intake (FI), condition factor $(\mathrm{K})$, feed conversion ratio (FCR), protein efficiency ratio (PER), survival rate (SR), hepatosomatic index (HSI), and gonadosomatic index (GSI). Calculations were carried out using the following formulae: weight gain $(\mathrm{g})=$ final weight-initial weight; specific growth rate $(\% /$ day $)=100(\ln W 2-\ln W 1) / T$, where $\mathrm{W} 1$ and W2 are the initial and final weight, respectively, and $T$ is the number of days in the experimental period; survival rate $(\%)=$ final number of fish $\times 100 /$ initial number of fish; condition factor $=100\left(\right.$ weight $/$ length $\left.^{3}\right)$; feed intake $=$ total dry feed/number of fish; feed conversion ratio $(\mathrm{FCR})=$ feed intake/live weight gain; protein efficiency ratio $(P E R)=$ live weight gain/protein fed, where protein $\mathrm{fed}=\%$ protein in diet $\times$ total diet consumed/100; HSI = 100 (liver weight/body weight); GSI = 100 (gonad weight/body weight).

\section{Statistical analysis}

All results were expressed as mean $\pm \mathrm{SD}$. Data were statistically analyzed using one-way analysis of variance (ANOVA-1) repeated measure followed by NewmanKeuls multiple tests with $n=3$ replicates. Differences were considered significant when $P<0.05$. All statistics were carried out using GraphPad Prism version 6.0.

Table 2 water quality parameters (Mean \pm SD) during 70 days of the experimental period

\begin{tabular}{|c|c|c|c|c|c|c|}
\hline \multirow[t]{2}{*}{ Parameters } & \multicolumn{6}{|c|}{ Rearing period (daRearing period (days) } \\
\hline & 0 & 14 & 28 & 42 & 56 & 70 \\
\hline Temperature $\left({ }^{\circ} \mathrm{C}\right)$ & $28.10 \pm 0.35$ & $28.10 \pm 1.10$ & $28.71 \pm 0.70$ & $28.1 \pm 0.80$ & $28.71 \pm 0.70$ & $27.96 \pm 0.70$ \\
\hline Dissolved oxygen (mg/l) & $5.56 \pm 0.25$ & $5.46 \pm 0.35$ & $5.56 \pm 0.32$ & $5.55 \pm 0.28$ & $5.55 \pm 0.38$ & $5.55 \pm 0.37$ \\
\hline $\mathrm{pH}$ & $7.20 \pm 0.03$ & $7.34 \pm 0.10$ & $7.35 \pm 0.10$ & $7.36 \pm 0.10$ & $7.22 \pm 0.20$ & $7.17 \pm 0.20$ \\
\hline Transparency (cm) & $36.60 \pm 4.44$ & $36.61 \pm 3.70$ & $37.23 \pm 3.40$ & $37.23 \pm 4.00$ & $38.85 \pm 4.10$ & $36.28 \pm 2.20$ \\
\hline Ammonia (mg/l) & $0.58 \pm 0.02$ & $0.50 \pm 0.05$ & $0.50 \pm 0.05$ & $0.50 \pm 0.00$ & $0.50 \pm 0.08$ & $0.50 \pm 0.02$ \\
\hline Nitrite $(\mathrm{mg} / \mathrm{l})$ & $0.03 \pm 0.00$ & $0.03 \pm 0.00$ & $0.03 \pm 0.00$ & $0.03 \pm 0.00$ & $0.03 \pm 0.00$ & $0.03 \pm 0.00$ \\
\hline Nitrate (mg/l) & $0.12 \pm 0.01$ & $0.12 \pm 0.01$ & $0.12 \pm 0.02$ & $0.12 \pm 0.05$ & $0.12 \pm 0.05$ & $0.12 \pm 0.05$ \\
\hline
\end{tabular}




\section{Results}

\section{Growth performances}

Growth performances of O. niloticus juveniles fed with different diet in terms of weight gain and specific growth rate are presented in Fig. 1. The weight gain recorded during fish sampling showed an increase with respect to time but not according to the G. kola supplementation rate (Fig. 1a). Feed supplemented with G. kola at 6\% induced in O. niloticus juveniles the highest values of weight gain as from the fourteenth day of the experiment up to the end. At the end of sampling, fish fed with diet supplemented with $6 \%$ of $G$. kola presented a weight gain of $19.46 \pm 1.31 \mathrm{~g}$, which was significantly $(p<0.05)$ higher by $17.68 \%$ and $32.58 \%$ compared to that in fish fed with the normal diet $(16.02 \pm 1.55 \mathrm{~g})$ and diet supplemented with $10 \%$ G. kola $(13.12 \pm 1.58 \mathrm{~g})$ respectively (Fig. 1a). Observation on specific growth rate showed significant $(p<0.05)$ increase in fish receiving a diet containing G. kola at $6 \%$ compared to fish fed with both the normal diet and diet supplemented with $10 \%$ G. kola during the first two rearing periods (Fig. 1b).

\section{Survival and feeding efficiency}

The results presented in Table 3 illustrate the survival rate and feeding efficiency in term of condition factor, feed intake, protein intake, feed conversion ratio, and protein efficiency ratio on the 70th day of the experiment. No mortality was recorded during the culture period. Similarly, no significant variation in condition factor and feed conversion ratio was observed among the different groups during the study. However, for the feed intake, Protein intake and Protein efficiency, significant differences were obtained only in fish fed diet supplemented with G. kola at 6\% compared to that receiving diet supplemented with G. kola at $10 \%$.
Body weights and organs measurements of sexually mature Oreochromis niloticus

The average body weights, hepatosomatic index, and gonadosomatic index per treatments in both males and females were computed and were presented in Figs. 2 and 3. In males, the mean values of body weight (Fig. 2), hepatosomatic index (Fig. 3a), and gonadosomatic index (Fig. 3b) among the different groups were not significantly different. After 70 days of experiment, the mean body weights of $36.77 \pm 3.62 \mathrm{~g}$ obtained in females fed with $6 \%$ G. kola supplemented diet was significantly $(p<$ $0.05)$ high compared to the control group (25.87 \pm 3.32 g) and groups fed with $10 \%$ G. kola supplemented diet $(26.33 \pm 3.34$ g) (Fig. 2). Moreover, feeding the female $O$. niloticus with a diet supplemented with G. kola significantly $(p<0.05)$ decreased both hepatosomatic index and gonadosomatic index compared to the control group (Fig. 3a, b).

\section{Discussion}

Fish is one of the most appreciated foodstuff worldwide and particularly in most of the African countries like Cameroon. However, despite the increase in production of cultured fish from some countries, production from some other countries including Cameroon has not improved yet; statistics show that the supply of fish in Cameroon comes to $43 \%$ of fishing ( $22 \%$ of inland fisheries, $21 \%$ of sea fisheries), $56.8 \%$ of imports and only $0.1 \%$ of fish farming, that is $1000 \mathrm{t} /$ year (FAO, 2009; Ndah et al. 2011). One of the reasons for low aquaculture production has been attributed to feeding quality. Research is currently focused on improving the quality of fish feed through replacement or addition of appropriate ingredients that encourage faster fish growth. Tropical forests contain many tree species that have supplied edible fruits for centuries. It has been previously reported in many research works that different plant additives can enhance growth in some fish species such
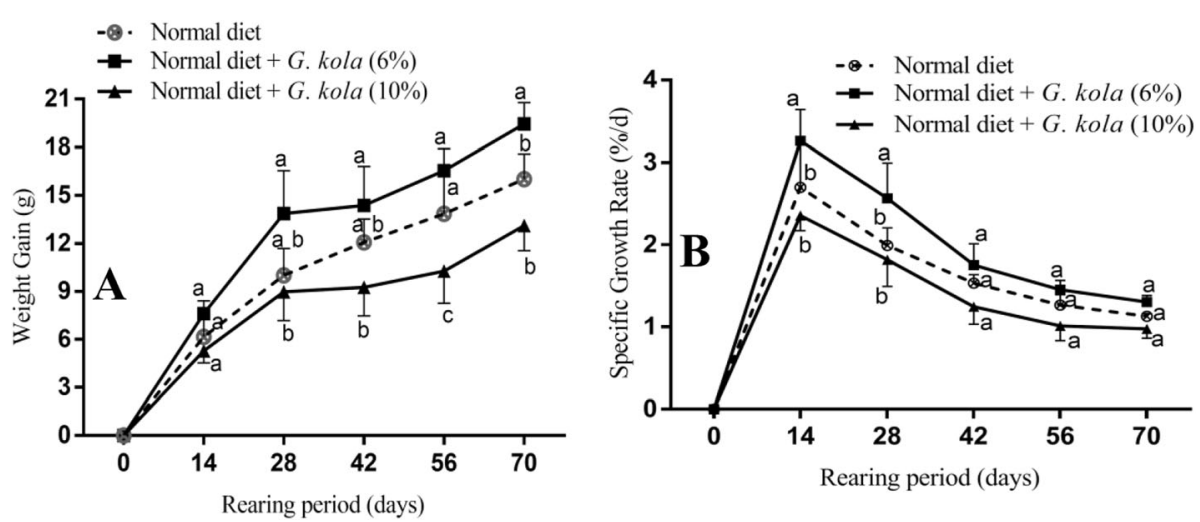

Fig. 1 Effects of diet supplementation with Garcinia kola seeds on mean weight gain (a) and specific growth rate (b) of Oreochromis niloticus juveniles. Mean on the same rearing period carrying the same superscript are not significantly different at $p<0.05$ 
Table 3 Survival and feed utilization of Oreochromis niloticus juveniles fed with different quantities of Garcinia kola supplemented diets for 70 days

\begin{tabular}{llll}
\hline Parameter & Normal diet & Normal diet + G. kola (6\%) & Normal diet + G. kola (10\%) \\
\hline Initial number & 36 & 36 & 36 \\
Final number & 36 & 36 & 36 \\
Survival rate (\%) & $100^{\mathrm{a}}$ & $100^{\mathrm{a}}$ & $100^{\mathrm{a}}$ \\
Initial biomass (g) & $159.86 \pm 8.71$ & $158.15 \pm 6.87$ & $161.72 \pm 16.94$ \\
Final biomass (g) & $352.13 \pm 27.28$ & $391.63 \pm 13.66$ & $319.18 \pm 16.94$ \\
Initial weight (g) & $13.32 \pm 0.72$ & $13.18 \pm 0.57$ & $13.48 \pm 0.78$ \\
Final weight (g) & $29.34 \pm 2.27$ & $32.64 \pm 1.13$ & $26.60 \pm 1.41$ \\
Final length (cm) & $11.35 \pm 0.41$ & $12.35 \pm 0.10$ & $11.30 \pm 0.19$ \\
Condition factor & $2.00 \pm 0.10^{\mathrm{a}}$ & $1.73 \pm 0.04^{\mathrm{a}}$ & $1.84 \pm 0.03^{\mathrm{a}}$ \\
Feed intake (g/fish) & $69.94 \pm 4.68^{\mathrm{ab}}$ & $73.81 \pm 2.60^{\mathrm{a}}$ & $63.35 \pm 2.68^{\mathrm{b}}$ \\
Protein intake (g/fish) & $28.00 \pm 1.08^{\mathrm{ab}}$ & $29.56 \pm 0.60^{\mathrm{a}}$ & $25.37 \pm 0.62^{\mathrm{b}}$ \\
Feed conversion ratio & $4.39 \pm 0.30^{\mathrm{a}}$ & $3.80 \pm 0.10^{\mathrm{a}}$ & $4.87 \pm 0.37^{\mathrm{a}}$ \\
Protein efficiency ratio & $0.57 \pm 0.03^{\text {ab }}$ & $0.66 \pm 0.01^{\mathrm{a}}$ & $0.52 \pm 0.04^{\mathrm{b}}$ \\
\hline
\end{tabular}

Values are mean \pm standard deviation of 3 replications containing 12 fish per replicate. Values on the same row carrying the same letter are not significantly different at $p<0.05$

as Oreochromis niloticus (Kareem et al. 2016, Hassan et al. 2018). Results from the present study indicate that there was an increase in the growth of the fish fed with different rate of dietary supplementation with G. kola seed. However, the highest growth response was observed in the fish fed with G. kola seed supplemented meal at a level of $60 \mathrm{~g} \mathrm{~kg}^{-1}$, indicating that the G. kola seed meal supplementation could have enhanced nutrient utilization, which is reflected in improved weight gain, specific growth rate, feed intake, feed conversion ratio, and protein efficiency ratio. In general, relatively high feed conversion ratio values were obtained in all treatments, but the best occurred in fish fed with $60 \mathrm{~g}$ $\mathrm{kg}^{-1}$ G. kola seed meal inclusion even though differences

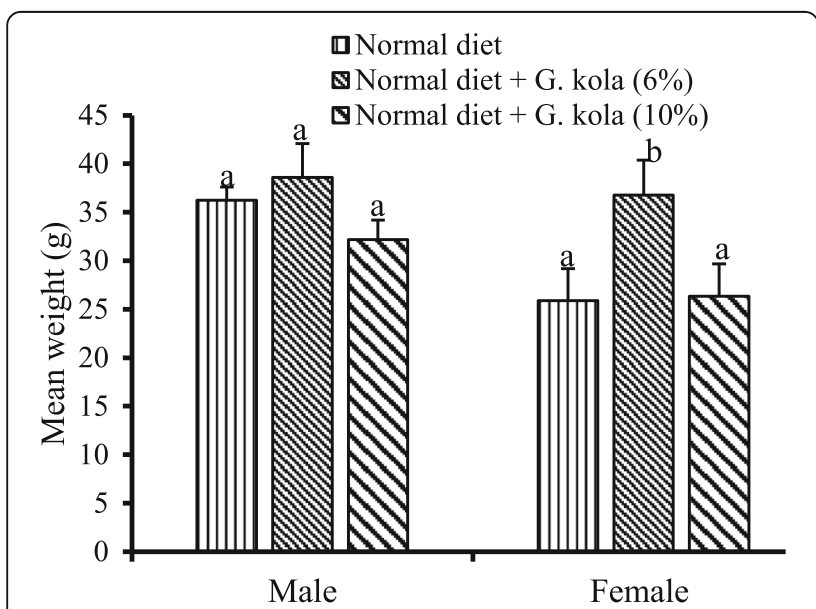

Fig. 2 Mean weight of male and female Oreochromis niloticus fed Garcinia kola during 70 days. Different letters indicate significant differences at $p<0.05$ among the treatment means were not significant. Previous studies revealed that G. kola seed powder supplemented in animal diets also promoted growth and feed conversion efficiency in Clarias gariepinus juveniles (Adeniji et al. 2018) and Oreochromis niloticus adults (Sulem-Yong et al. 2018). The proximate and phytochemicals analysis of $G$. kola seeds revealed that it is rich in nutrients such as, vitamins, minerals, phytochemicals but low in anti-nutrients content, indicating that it could be used as supplements in feed manufacturing (Adesuyi et al. 2012; Mazi et al. 2013; Onyekwelu et al. 2015). According to Onyekwelu et al. (2015), the low antinutrients content in G. kola indicates that its consumption would not pose nutritional or health problems. Moreover, the low protein content observed in the G. kola seeds can be indicative that the growth response observed in fish fed with G. kola supplemented diet might not be attributed to its nutritional value but mostly to its bioactive compounds. Diab et al. (2008) reported that $O$. niloticus fingerlings fed with medicinal plants supplemented diets exhibited faster growth than those fed with the control diet. According to Kim et al. (1998) unknown factors in various medicinal herbs might lead to favorable results in fish growth trials. Phytochemicals such as phenolic compounds and flavonoids are known as non-nutritive plant chemicals that have protective or disease preventive properties. They are present naturally in seeds, flowers, fruits, vegetables, nuts, and bark of a variety of plants that interplay with nutrients and dietary fiber to protect them (Mazur, 2000). Phytochemicals analysis of G. kola seeds revealed the presence of phenols and flavonoids in appreciable amounts (Onyekwelu et al. 2015). It has been established 


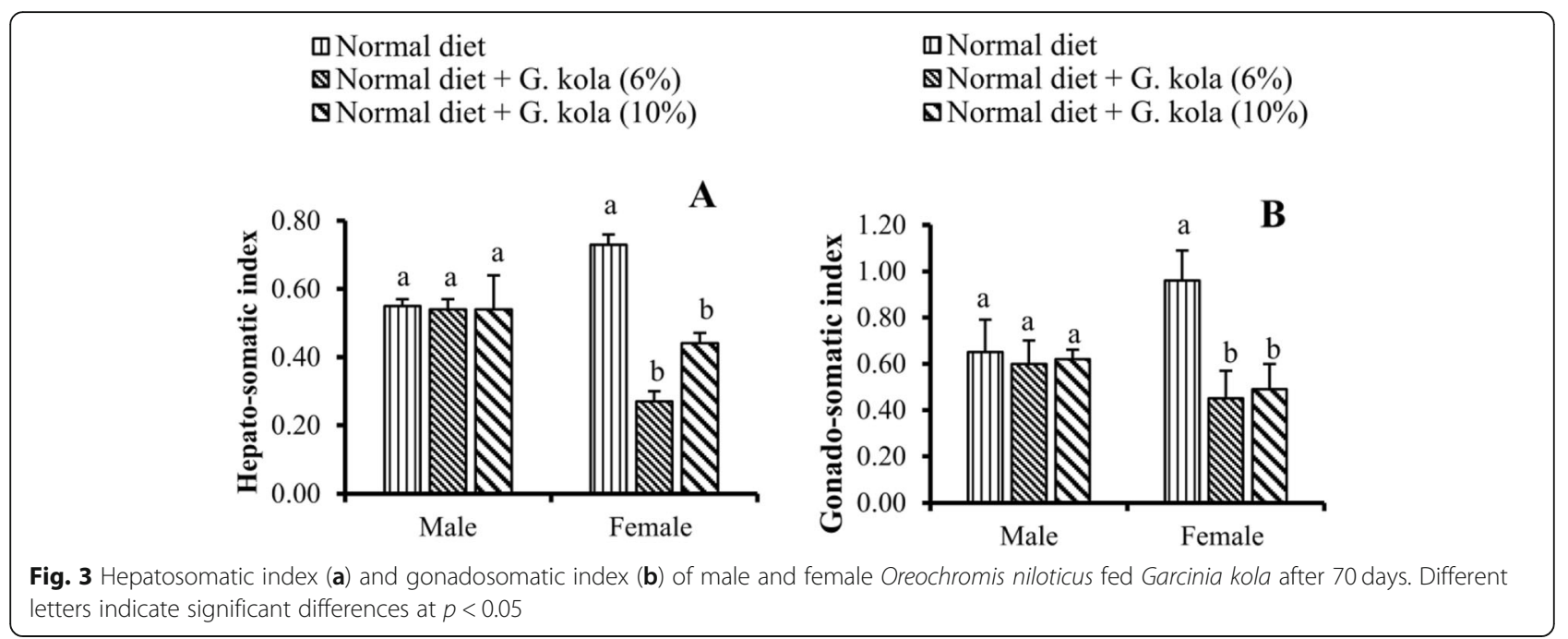

that phenols and flavonoids possess many properties which makes them vital to both plants and animals. Some of these properties are their antioxidant potential that protects cells against oxidative damage, antimicrobial properties, and physiological activities. Sim and Nurestri, 2010) also reported that fruits with high phenolic contents generally show stronger antioxidant activities. Thus, the results of the present findings may be due to the presence of bioflavonoids in G. kola that would have stimulated growth in both the males and females' experimental $O$. niloticus juveniles, certainly by improving feed intake and feed utilization. In addition, bioflavonoids are known as plant chemicals with estrogenic activity, and studies have shown that estrogen promotes growth in common carp (Kocour et al. 2005). As aforementioned above, phytochemical studies of Garcinia kola seeds have revealed relatively low levels of antinutritional compounds such as tannin, oxalate, phytate, and trypsin inhibitor (Omeh et al. 2014, DahNouvlessounon et al. 2015). However, the increase in dietary supplementation of G. kola is naturally followed by that of the above-mentioned anti-nutritional components. Thus, the low growth in O. niloticus juveniles fed with dietary supplementation of G. kola seeds at $10 \%$ compared to that at $6 \%$ might be probably attributed to the increased in anti-nutritional components level in the diet, which would have reduced the secretion of bile and the activity of digestive enzymes as describe by Kaur and Shah (2017).

The first sexual maturity in fish is strongly related to size. According to Gnoumou et al. (2018), size at first sexual maturity in $O$. niloticus depends on the environmental conditions in which the fish grows. Thus, when conditions are favorable, the size at first maturity increases while it decreases when conditions are unfavorable. Under natural conditions, tilapia reaches sexual maturity at a later age and at a higher weight than that raised in culture ponds. For instance, it is established that in several natural lakes in East Africa, O. niloticus matures at about 10 to 12 months at a size of 350 to $500 \mathrm{~g}$. The same population in farm or culture ponds, under conditions of near-maximum growth, will reach sexual maturity at an age of 5 to 6 months and 150 to $200 \mathrm{~g}$ (Popma and Lovshin, 1995). Under poor conditions of rural fish breeding, farmed tilapias often reach sexual maturity in 3 to 6 months at a size of $15-20 \mathrm{~g}$ and spawn before they reach marketable size (Mair and Little, 1991). The results of this study showed that all the fish presented a size above $20 \mathrm{~g}$ with the highest size above $35 \mathrm{~g}$ in both males and females O. niloticus fed with G. kola at $6 \%$ inclusion rate in the diet. Accordingly, the fish used in the present study would have reached their first sexual maturity. Results on GSI and HSI in males revealed no statistically significant changes between treatments; while in females, the GSI and HSI indices of the experimental groups were significantly lower than those obtained in normal females. Similar results were also obtained by Kareem et al. (2016) during their study on the effects of some dietary crude plant extracts on the growth and gonadal maturity of Nile tilapia (Oreochromis niloticus) and their resistance to Streptococcus agalactiae infection and by Ramírez et al. (2017) while studying the effect of Passiflora incarnata (L) extract on gonadal maturation in young Tilapia (Oreochromis $\mathrm{sp}$ ). This could indicate that dietary inclusion of $G$. kola seeds powder in addition to its effects as growth promoter in both males and females' Oreochromis niloticus, might also exert its physiological effects on the female's reproductive system by delaying or inhibiting gonadal maturation. As it is known, early sexual maturity in Tilapia culture is a well-recognized problem which results in inbreeding in overstocked fish ponds, reduced 
production, and farmed stocks of generally low quality (Kumar et al. 2018). The low value of the gonadosomatic index obtained in O. niloticus females fed G. kola supplementation compared to the control group indicates a slowing of the development of the ovaries whose consequence would be a delay in sexual maturity. This shows that the use of G. kola as a feed additive would be beneficial to the Tilapia farmer. This could help to reduce the production cost and even the time the fish farmer use during pond management. These effects might be related once more to the presence of bioactive compounds such as flavonoids, known as one of the main classes of phytoestrogens present in a variety of plants (Mazur, 2000). According to Patisaul and Jefferson (2010), the US Environmental Protection Agency (EPA) described "phytoestrogens as naturally occurring plant compounds that are structurally and/or functionally similar to mammalian estrogens and their active metabolites." These compounds have the capacity to alter the structure or function(s) of the endocrine system and cause adverse effects including the timing of puberty, capacity to produce viable and fertile offspring, sex-specific behavior, premature reproductive senescence, and compromise fertility. According to Cheshenko et al. (2008), phytoestrogens might act by inhibiting steroidogenic enzymes through competitive inhibition with natural substrates for a particular enzyme. They are also able not only to bind to respective receptors, but also to directly interact with aromatase CYP19, possibly leading to inhibition of this enzyme involved in the synthesis of 17ß-estradiol, thereby affecting reproductive health of the fish.

Oreochromis niloticus being one of the famous species reared in Cameroon, its growth, metabolism, and reproduction are greatly influenced by the water quality parameters of the culture environment. Water quality is the most important limiting factor in pond fish production as its quality directly affects feed efficiency, growth rates, the fish's health, and survival, as well as the fish reproductive cycle. Any changes in the fish environment add stress to the fish and the higher and faster the changes, the greater the stress. So, the maintenance of the physico-chemical parameters within the acceptable limits are very essential for getting maximum yield in a fish pond (Bhatnagar and Dev, 2013). The water quality parameters revealed the environmental conditions under which the fish were cultured during this study. The average values of water quality parameters such as temperature, transparency, $\mathrm{pH}$, dissolved oxygen, nitrite, nitrate, and ammonia monitored throughout the trials were considered as suitable for the survival, normal growth, as well as good general physiology of $O$. niloticus. These values were in accordance with the findings of Yoo and Lee, 2016, Makori et al. 2017 and Nyadjeu et al. (2018) and could partially justify the absence of mortality observed throughout the study, coupled with experimental fish's apparent good health observed through the results on both the growth and feed utilization.

\section{Conclusion}

The results of this study show that supplementation of $G$. kola seeds powder at $6 \%$ in diets of Oreochromis niloticus juveniles induced the best effect on growth performances. However, on the gonadal development, dietary supplementation of G. kola irrespective to the level of inclusion, highly inhibited gonadal development in Oreochromis niloticus females; suggesting that for a sustainable development in Tilapia culture, G. kola seeds could be used as growth-promoting agent and also control prolific breeding through its capacity to inhibit ovary development.

\section{Acknowledgements}

The authors sincerely thank Mr. Nkamegni Noupeu Roger, manager of a private fish farm in Bomabom Village, Cameroon, for providing the technical infrastructure to carry out this study.

\section{Authors' contributions}

PN contributed to the study design, data analysis, and writing of the manuscript. JA contributed to the study design and sample collection. NPN drafted the manuscript. METT helped in the study design. All authors reviewed, edited, and approved the manuscript for submission.

\section{Funding}

This work did not receive any grant. It was funded by the authors of the manuscript.

\section{Availability of data and materials}

All datasets generated during and/or analyzed during the current study are available from the authors on reasonable request.

Ethics approval and consent to participate

Not applicable

Consent for publication

Not applicable

Competing interests

The authors declare that they have no competing interests.

Author details

${ }^{1}$ The University of Douala, Institute of Fisheries and Aquatic Sciences of Yabassi, P.O. Box: 7236, Douala, Cameroon. ${ }^{2}$ College of Technology, The University of Bamenda, P.O. Box 39, Bambili, Bamenda, Cameroon.

Received: 23 January 2019 Accepted: 4 September 2019

Published online: 18 September 2019

\section{References}

Adeniji AR, Osifeso OO, Abiodun W, Yusuff KO, Agidigbi OR. Effect of supplementation of Garcinia kola (bitter Kola) on the growth performance of Clarias gariepinus (catfish) juveniles. Sci Eng Perspect. 2018;13:45-50. Adesuyi AO, Elumm IK, Adaramola FB, Nwokocha AGM. Nutritional and phytochemical screening of Garcinia kola. Adv J Food Sci Technol. 2012;4(1):9-14 AOAC, Association of Official Analytical Chemist (AOAC). Official Methods of Analysis Association of Official Analytical Chemists, 15 th Edn. Washington DC; 1990. p. 1298.

Bhatnagar A, Devi P. Water quality guidelines for management of pond fish culture. Int J Environ Sci. 2013;3(6):1980-2009. https://doi.org/10.6088/ijes.20130600019.

Cheshenko K, Pakdel F, Segner H, Kah O, Egge RIL. Interference of endocrine disrupting chemicals with aromatase CYP19 expression or activity, and consequences for reproduction of teleost fish. Gen Comp Endocrinol. 2008: 155:31-62. 
Dah-Nouvlessounon D, Adjanohoun A, Sina H, Noumavo PA, Diarrasouba N, Parkouda C, Madodé YE, Dicko MH, Baba-Moussa L. Nutritional and anti-nutrient composition of three kola nuts (Cola nitida, Cola acuminata and Garcinia kola) produced in Benin. Food Nutr Sci. 2015;6:1395-407. https://doi.org/10.4236/fns.2015.615145.

Diab AA, Aly SM, John G, Abde-Hadi Y, Mohammed MT. Effect of garlic, black seed and blogen as immuniostimulants on the growth and survival of Nile Tilapia, Oreochromis niloticus (Teleostei: cichidae) and their response to artificial infection with Pseudomonas fluorescens. Afr J Aquat Sci. 2008;33:63-8.

FAO. Rapport panorama I sur les statistiques agricoles et alimentaires. Cameroun. CountryStat pour l'Afrique Sub-Saharienne. Rome; 2009. p. 178.

Gnoumou SP, Oueda A, Ndiaye A, Gneme A, Guenda W, Ndiaye P, Kabre BG. Some reproductive aspects of Oreochromis niloticus (LINNAEUS, 1758) at Peele reservoir, Nakanbé River Basin, Burkina Faso. Int J Fish Aquat Stud. 2018;6(4):124-30.

Hassan AAM, Yacout MH, Khalel MS, Hafsa SHA, Ibrahim MAR, Mocuta DNM, Rahoveanu AT, Dediu L. Effects of some herbal plant supplements on growth performance and the immune response in Nile tilapia (Oreochromis niloticus). Sciendo. 2018:134-41. https://doi.org/10.2478/alife-2018-0020.

Hussain SA. Fish as a vital source of animal protein. Progressive farming, 6 B, vol. 13; 1986.

Jegede T. Control of reproduction in Oreochromis niloticus (Linnaeus 1758) using Hibiscus Rosa-sinensis (Linn.) leaf meal as reproduction inhibitor. J Agric Sci. 2010;2(4):149-54.

Kareem ZH, Abdelhadi YM, Christianus A, Romano N, Karim M. Effects of some dietary crude plant extracts on the growth and gonadal maturity of Nile tilapia (Oreochromis niloticus) and their resistance to Streptococcus agalactiae infection. Fish Physiol Biochem. 2016;42:757-69. https://doi.org/10.1007/ s10695-015-0173-3.

Kaur R, Shah TK. A review on role of plant waste products on fish growth, health and production. J Entomol Zool Stud. 2017;5(3):583-9.

Kim DS, Noah CH, Jung SW, Jo JY. Effect of obosan supplemented diet on growth, feed conversion ratio and body composition of Nile tilapia, Oreochromis niloticus. Aquaculture. 1998;11:83-90.

Kocour M, Lynhard O, Gela D, Rodina M. Growth performance of all-female and mixed-sex common carp, Cyprinus carpio L. population in central European climatic conditions. J World Aquacult Soc. 2005;36:103-13.

Kumar GVP, Nikitha NM, Begum MH, Sekhar VC. Supplementation of materials in fish feed for efficient growth performance and body indices: an extensive review on the role of functional feed additives in tilapia nutrition. Int J Fish Aquat Res. 2018;3(4):13-22 ISSN: 2456-7248.

Madubunyi II. Antihepatotoxic principles of Garcinia kola seeds. Comp Clin Pathol. 2010;21:481-5.

Mair GC, Little DC. Population control in farmed tilapia. NAGA, ICLARM Quarterly. 1991;17(4):8-13.

Makori AJ, Abuom PO, Kapiyo R, Anyona DN, Dida GO. Effects of water physicochemical parameters on tilapia (Oreochromis niloticus) growth in earthen ponds in Teso north Sub-County, Busia County. Fish Aquat Sci. 2017;20:30. https://doi.org/10.1186/s41240-017-0075-7.

Manourová A, Leuner O, Tchoundjeu Z, Van Damme PV, Verner V, Pribyl O, Lojka B. Medicinal potential, utilization and domestication status of bitter kola (Garcinia kola Heckel) in west and Central Africa. Forests. 2019;10:124. https:// doi.org/10.3390/f10020124.

Mazi EA, Okoronkwo KA, Ibe UK. Physico-chemical and nutritive properties of bitter Kola (Garcinia kola). J Nutr Food Sci. 2013;3:218. https://doi.org/10. 4172/2155-9600.1000218.

Mazur W. Phytoestrogens: Occurrence in Foods, and Metabolism of Lignans in Man and Pigs. PhD Thesis, Helsinki 2000 Division of Clinical Chemistry, University of Helsinki, and Institute for Preventive Medicine, Nutrition and Cancer, Folkhälsan Research Center, Helsinki, Finland. 2000; 141 p.

Ndah HT, Knierim A, Ndambi OA. Fish pond aquaculture in Cameroon: a field survey of determinants for farmers' adoption behaviour. J Agric Educ Ext. 2011;17(4):309-23. https://doi.org/10.1080/1389224X.2011.576578.

NRC. Nutrient Requirements of Fish and Shrimp. National Research Council (NRC). Washington, DC: The National Academies Press; 2011. https://doi.org/10. 17226/13039.

Nyadjeu P, Djopnang JD, Mbatchou PN, Tabi-Tomedi ME, Tchoumbougnang F. Effect of fish meal substitution with lima bean meal on growth and feed utilization in common carp fry, Cyprinus carpio. Int J Biol Chem Sci. 2018; 12(2):812-21. DOI. https://doi.org/10.4314/ijbcs.v12i2.16.

Oluyemi KA, Jimoh OR, Adesanya OA, Omotuyi IO, Josiah SJ, Oyesola TO. Effects of crude ethanolic extract of Garcinia cambogia on the reproductive system of male wistar rats (Rattus novergicus). Afr J Biotechnol. 2007;6:1236-8.
Omeh YN, Onoja SO, Ezeja MI, Uchendu WC, Okorie E, Raymond M. Quantitative phytochemical, proximate analysis and Hypolipidemic effect of Garcinia kola. Br J Med Med Res. 2014;4(36):5770-8. https://doi.org/10.9734/BJMMR/2014/ 12259.

Onyekwelu JC, Mosandl R, Oyewale O, Stimm B. Antioxidant, nutritional and antinutritional composition of Garcinia kola and Chrysophyllum albidum from rainforest ecosystem of Ondo State, Nigeria. J For Res. 2015;26(2):417-24. https://doi.org/10.1007/s11676-015-0068-2.

Patisaul HB, Jefferson W. The pros and cons of phytoestrogens. Front Neuroendocrinol. 2010;31:400-19.

Phelps RP. Hormone manipulation of sex. Pp 211-252. In: Lim CE, Webster CD, editors. Tilapia- biology, culture and nutrition. New York: Food products press. An imprint of the Haworth press, Inc; 2006. 645p.

Popma TJ, Lovshin LL. Worldwide Prospects for Commercial Production of Tilapia International Center for Aquaculture and Aquatic Environments. Department of Fisheries and Allied Aquacultures. Alabama: Auburn University; 1995. p. 42.

Ramírez E, López-Cardiel J, Lezama C, García-Márquez L, Borja-Gómez I, TintosGómez A. Effect of Passiflora incarnata $(\mathrm{L})$ extract on gonadal maturation in young tilapia (Oreochromis sp.). Lat Am J Aquat Res. 2017;45(5):908-14. https://doi.org/10.3856/vol45-issue5-fulltext-5.

Shelton WL. "Tilapia culture in the 21st Century), In: Guerrore, R.D III and Guerrero-Del Castillo, M,R (Eds), Proceedings of the International Forum on Tilapia Farming in the 21st Century (Tilapia Forum 2002). Los Bamos: Philippine Fisheries Association Inc.; 2002. pp 1-20.

Sim K, Nurestri AS. Norhanom a phenolic content and antioxidant activity of Pereskia grandifolia haw. (Cactaceae) extracts. Pharmacogn Mag. 2010;6:248-54.

Sosa IDLAB, Adillo MDLJ, Ibanez AL, Figueroa JLIA. Variability of tilapia (Oreochromis spp) introduced in Mexico: Morphometric, meristic and genetic characters. J Appl Ichthyol. 2005;20:7-10.

Sulem-Yong NN, Sandjoh R, Angoun J, Nzoko AF, Mounjouenpou P, Agbor KE, Yong-Sulem S. Effect of varied dietary bitter Kola (Garcinia Kola) seeds levels on spawning of Nile tilapia (Oreochromis Niloticus L.). Int J Fish Aquat Stud. 2018;6(2):507-10

Tigoli K, Cisse M, Kone M, Ouattara M, Ouattara A, Gourene G. Effects of two African aphrodisiatic plants Garcinia kola and Turraea heterophylla on zooetchnic performances and sexual inversion rate in Oreochromis niloticus. Agron Afr. 2018;30(2):135-46.

Yoo G-Y, Lee J-Y. The effect of feeding frequency, water temperature, and stocking density on the growth of river puffer Takifugu obscurus reared in a zero-exchange water system. Fish Aquat Sci. 2016;19:23. https://doi.org/10. 1186/s41240-016-0024-x.

\section{Publisher's Note}

Springer Nature remains neutral with regard to jurisdictional claims in published maps and institutional affiliations.

Ready to submit your research? Choose BMC and benefit from:

- fast, convenient online submission

- thorough peer review by experienced researchers in your field

- rapid publication on acceptance

- support for research data, including large and complex data types

- gold Open Access which fosters wider collaboration and increased citations

- maximum visibility for your research: over $100 \mathrm{M}$ website views per year

At $\mathrm{BMC}$, research is always in progress.

Learn more biomedcentral.com/submissions 